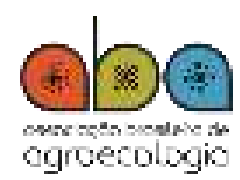

ISSN: $1980-9735$

DOI: 10.33240/rba.v16i1.23319

Vol. 16 | No 1 | p.104-105 | 2021

RESUMO DE DISSERTACÃO

\title{
AGROECOLOGIA CAMPONESA: MUITO ALÉM DA PRODUÇÃO DE ALIMENTOS SAUDÁVEIS - UM PROJETO DE VIDA NO ASSENTAMENTO CONTESTADO, LAPA/PR
}

\author{
Peasant agroecology: far beyond the production of healthy food, a life project in the \\ Contestado settlement, Lapa / PR
}

Nathan Pereira Dourado'

\section{RESUMO}

Correntemente o conceito de desenvolvimento está associado a uma noção positiva, como um processo inexorável para passar de uma dada situação para outra melhor. Por isso, está presente nos discursos e práticas políticas, exercendo um forte poder mobilizador. No entanto, notamos que o desenvolvimento apresenta uma série de contradições em um sistema mundo capitalista modernocolonial. Na maioria dos casos o discurso desenvolvimentista inspira falsas promessas e a sua prática manifesta diversas controvérsias, limitando os processos de transformação social efetivos. A ideologia do desenvolvimento junto ao avanço destrutivo do capital, em curso no espaço rural brasileiro, já não consegue acomodar as suas intensas contradições. Buscamos com este trabalho, apresentar as contradições em torno deste conceito e dar destaque a uma das múltiplas linhas de argumentação no debate contemporâneo sobre o fenômeno do desenvolvimento, empreendida pela corrente teórica do pós-desenvolvimento; assim, visamos ampliar o quadro de debates atuais e reforçar a coerência teórica e prática das iniciativas de resistências e de alternativas contra hegemônicas. Nesse sentido, buscamos também identificar convergências entre os conceitos de Agroecologia e Bem Viver, como uma possível resposta aos anseios e críticas elaborados pela corrente do pós-desenvolvimento. 0 estudo empírico apresentado neste trabalho refere-se ao Assentamento Contestado no município da

${ }^{1}$ Geógrafo (UNIFAL-MG), Mestre em Agroecossistemas (USFC), Doutorando em Geografia (UFBA)

Curso de Mestrado em Agroecossistemas, Centro de Ciências Agrárias, Universidade Federal de Santa Catarina, Florianópolis, 2019. $124 \mathrm{f}$.

Orientador: Profa. Dr. Clarilton Edzard Davoine Cardoso Ribas Coorientadora: Profa. Dra. Marlene Grade

\section{Ano de defesa: 2019}

Recebido em: 23/06/2020 Aceito em: $23 / 06 / 2020$

Correspondência para: npdourado@hotmail.com
Lapa - PR. Partimos da hipótese que o assentamento constitui-se numa negação ao caráter destrutivo do padrão de desenvolvimento hegemônico, e exprime uma crítica empírica aos limites do capital manifestando racionalidades alternativas - podendo ser visto como um lugar de manifestação do Bem Viver e um possível embrião de renovadas relações sociais pós-desenvolvimentistas. O objetivo da pesquisa é analisar as contribuições da Agroecologia na edificação do Bem Viver - como alternativa ao desenvolvimento. A pesquisa possui natureza qualitativa e combina pesquisa bibliográfica e documental com observação em campo e entrevistas semiestruturadas. Os resultados permitem considerar o assentamento Contestado como um experimento real em que camponeses e camponesas se organizam para produzir e viver a agroecologia, passando a manifestar novas formas de relação entre si, com a natureza e com o trabalho. Os elementos constitutivos de um Bem Viver agroecológico, apontados como tendência no assentamento Contestado, foram: racionalidade ambiental, emancipação humana, convivencialidade, soberania alimentar e promoção da saúde.

Palavras-Chave: Bem-viver. Pós-desenvolvimento. MST. Campesinato. 


\section{ABSTRACT}

Nowadays the development concept is associated with a positive notion, like an unrelenting process from a given situation to a better one. Because of that, it is present in the politic speeches and practices, exercising a strong mobilizing power. Meanwhile, we can notice that development presents a series of contradictions in a capitalistic modern-colonial worldsystem. In most cases the developmental speech inspires false promises, and their practices shows different controversies, limiting the effectives social transformation processes. The development ideology, together with the destructive advance of the capital, ongoing in the Brazilian rural areas, cannot accommodate its intense contradictions anymore. With this work we try to present the contradictions around this concept and to emphasize one of the multiples argumentation lines in the contemporary debate about the phenomenon, taken by the post-development theoretic current; this way we want to extend the actual debate framework and to boost the theoretic and practical coherence of the resistance's initiatives and contrahegemonic initiatives. In this sense, we also try to identify some convergences between Agroecology and Good Life concepts, like a possible answer to essays and critics elaborated by the post-development current. The empiric study presented in this work relates to the Contestado settlement in the district of Lapa/PR. We start from the hypothesis that the settlement takes form in a denial to the destructive nature of the hegemonic development pattern, and it expresses an empiric criticism to the capital limits manifesting alternatives rationalities - possibly be a manifestation of Good Life place and a possible embryo of post-development renovated social relationships. The aim of this research is to analyze the Agroecology contributions to the Good Life construction - as an alternative to development. The research owns qualitive nature and combines bibliographic and documentary research with field observation and semi structured interviews. The results permit to consider the Contestado settlement as a real experiment in which the farmers, male and female, organize themselves in order to product and live the agroecology, switching to manifest new ways of relationship between them, the nature and work. The constructive elements of an agroecological Good Life, appointed as a tendence into the Contestado settlement, were: environmental rationality, human emancipation, conviviality, food sovereignty and health promotion.

Keywords: Well-being. Post-development. MST. Peasantry. 